\title{
Profile Characteristic of Rice Drum Seeder Technology Farmers in Khammam District of Telangana State, India
}

\author{
B. Naresh Kumar ${ }^{1 *}$, M. Sreenivasulu ${ }^{2}$, M. Preethi ${ }^{3}$ and G.E.CH. Vidya Sagar ${ }^{4}$ \\ ${ }^{1}$ Masters in Agricultural Extension, ${ }^{2}$ Department of Agricultural Extension, ${ }^{4}$ Department of \\ Agronomy, PJTSAU, College of Agriculture, Rajendra Nagar, Hyderabad, India \\ ${ }^{3}$ Extension Education Institute (EEI), Rajendra Nagar, Hyderabad, India \\ *Corresponding author
}

\section{A B S T R A C T}

\begin{tabular}{|l|}
\hline Ke y w o r d s \\
Rice drum seeder \\
Technology, Ex- \\
post facto research, \\
Profile \\
characteristics
\end{tabular}

\section{Introduction}

Rice is one of the most important crops of India and occupies 23.3 percent of gross cropped area of the country. Rice contributes 43 percent of total food grain production and 46 percent of total cereal production. India has largest area under rice crop and is about 45 million hectares. To meet the demands of the growing population rate, rice production should rise to 120 million tonnes by 2020 . The total rice growing area in Telangana state is about 19.28 lakh hectares. The area under cultivation of paddy in Kharif is 11.68 lakh ha and in Rabi it is 7.60 lakh ha. Productivity of the crop is about 3.54 tonnes/ ha in both the seasons during 2015-16. Paddy is the staple food crop of Telangana state, where in more than 75 percent of paddy production is recorded from Nalagonda, Karimnagar, Nizamabad, Warangal and Khammam districts. To achieve target rice production for ever growing population with available land and water resources, direct seeding with drum 
seeder is needed. Although the drum seeding method has advantages and disadvantages, its rapid spread in various parts of Asia indicates that the net economic benefit has been positive. Despite a lower average yield, drum seeded rice has a higher net profit, with the savings in labour cost. This has occurred especially in areas where labour cost has risen rapidly in relation to the rice price. In addition, total farm income has increased because drum seeding facilitated double cropping of rice in areas where only one crop of transplanted rice is grown.

\section{Materials and Methods}

An Ex-post-facto research design was adopted for the study, as the variables chosen for the study has already occurred. Khammam district of Telangana state was purposively selected as it is one of the leading rice producing districts of Telangana state with highest cultivated area under drum seeder technology. Three mandals were selected purposively based on the area under rice drum seeder technology. From the selected mandals, four villages from each mandal were selected at random. Thus a total of 12 villages were selected for the study. From each village, 10 practicing farmers of Rice drum seeder technology were selected randomly, thus making a total sample of 120 respondents for the study. Data was collected with well-structured schedule and obtained data was coded, classified and tabulated. Frequencies and percentages were calculated and ranking was given in the order of magnitude.

\section{Results and Discussion}

Majority $(52.50 \%)$ of the respondents belonged to middle age followed by old age and young age categories. The probable reason might be that young farmers have been engaged in activities other than agriculture, old farmers, may be due to their traditional outlook and also being less energetic are unwilling to cultivate rice drum seeder technology as it is very innovative and needs constant field supervision. Hence majority of rice drum seeder cultivators are found to be middle aged farmers. The findings were in conformation with results of Kiran and Shenoy (2010) and Nirmala (2012).

Majority $(34.16 \%)$ of the respondents were illiterate followed by primary school education, Secondary school education and college level and above. The reason for more number of respondents to be in illiterate category might be due to absence of enough formal educational institutes and majority respondents are middle to old age category.

Hence the government should take care of improving education institutions to improve literacy rate of farmers in particular villagers in general. The findings were in conformation with results of Prasad (2002).

Majority $(51.67 \%)$ of the respondents had medium farm size followed by large and small farm size. The possible reason might be that in the recent times most of the families are of nuclear system and joint family system is gradually fading away. This resulted in fragmentation of land among the family members. As the majority of farmers are of medium and large farm size, extension agencies have to take care of technologies, which give sustainable production yields in available land. The findings were in conformation with results of Prasad (2002).

Majority of the respondents had low farming experience $(48.33 \%)$ followed by medium and high $(15.00 \%)$ farming experience. Since majority of the respondents belonged to middle age category, they were found to possess medium farming experience. The findings were in conformation with the results of Nirmala (2012) and Praveen babu (2014). 
Majority (49.17\%) of the respondents had medium level of annual income followed by high and low levels of annual income. Since majority of the respondents possess medium farm size, they were found to possess medium annual income category. This result was in conformation with results of Manjunath (2010), Anup (2010) and Praveen babu (2014).

Majority of the respondents [45.83] had medium to low level of extension contacts with the government, non-government and private extension agencies. This might be due to the fact that as majority of respondents were illiterate and primary school education they may not be having frequent contact with officials. Inadequate staff is another reason. These results were in confirmation with the findings of Viresh and Kiran (2007), Arathy (2011) and Praveen babu (2014).

Majority $(50.00 \%)$ of the respondents had medium mass media exposure followed by low and high levels of mass media exposure. This trend might be due to the fact that majority of the respondents were illiterate and primary school education. Almost every household possessed television, they were keen on watching television and listening to radio. Like this they also shown much attention to print media as it is available at lower rate. Hence they showed more interest towards print media, educational films, and agricultural programmes in television etc. The findings were in conformation with findings of Nagadev and Venkataramaiah (2007), Kiran and Shenoy (2010), Arathy (2011) and Praveen babu (2014). Majority (59.17\%) of the respondents had medium innovativeness followed by high and low innovativeness. The possible reasons might be that majority of the respondents involved in rice drum seeder technology were of middle to old aged category and innovativeness is generally associated with younger age. But it was observed that respondents possess medium extension contact and source of information utilisation were curious about new cultivation methods as they were cultivating the crop from generations together and they have shown more interest on the latest developments of Paddy technology. This result was in conformation with results of Rajendra Kumar (2002), Obaiah (2004), Arathy (2011) and Nirmala (2012).

Majority (52.50\%) of the respondents had utilised sources of information to the medium extent followed by low and high utilisation of information sources. As majority of the respondents were illiterate and primary school education category with medium to low extension contacts, their sources of information utilisation was also found to be ranging from medium to low levels. The results were in confirmation with the findings of Nirmala (2012), Shamna (2015) and Kiran and Shenoy (2010).

The findings revealed that 69.17 per cent of the respondents received only medium to low trainings. The reason could be their medium to low extension contacts and sources of information utilisation. As the contacts maintained by respondents with extension agencies and the information sources utilised were on the lower side coupled with their poor educational back ground led to lesser number of trainings attended by the respondents. The results were in confirmation with the findings of Sowjanya (2005), Gangadhar (2009) and Shamna (2015). Majority (43.33\%) of the respondents had medium level of risk orientation followed by high and low levels of risk orientation. The possible reason for the result might be that majority of the respondents were illiterate and with medium to low extension contact, mass media exposure, source of information. The findings were in conformation with results of Nirmala (2012) and Shaman (2015) (Table 1). 
Table.1 Profile characteristic of rice drum seeder technology farmers

\begin{tabular}{|c|c|c|c|}
\hline \multirow[t]{2}{*}{ Particulars } & \multirow[t]{2}{*}{ Category } & Total & \multirow{2}{*}{$\begin{array}{c}\mathbf{N}=\mathbf{1 2 0} \\
\text { Percentage }\end{array}$} \\
\hline & & Frequency & \\
\hline \multirow[t]{3}{*}{ Age } & Young age (below 35 years) & 20 & 16.67 \\
\hline & Middle age ( $35-55$ years0 & 63 & 52.50 \\
\hline & Old age (above 55years) & 37 & 30.83 \\
\hline \multirow[t]{4}{*}{ Education } & Illiterate & 41 & 34.16 \\
\hline & Primary school education & 32 & 26.67 \\
\hline & Secondary school education & 27 & 22.50 \\
\hline & College level and above & 20 & 16.67 \\
\hline \multirow[t]{3}{*}{ Farm size } & Small (,2.5 ha) & 27 & 22.50 \\
\hline & Medium $(2.5-5.0$ ha $)$ & 62 & 51.67 \\
\hline & Large $(>5.0 \mathrm{ha})$ & 31 & 25.83 \\
\hline \multirow[t]{3}{*}{ Farming experience } & Low & 44 & 36.67 \\
\hline & Medium & 58 & 48.33 \\
\hline & High & 18 & 15.00 \\
\hline \multirow[t]{3}{*}{ Annual income } & Low $(<65,000)$ & 17 & 14.17 \\
\hline & Medium $(65,000-1,50,000)$ & 59 & 49.17 \\
\hline & High (above $1,50,000$ ) & 44 & 36.66 \\
\hline \multirow[t]{3}{*}{ Extension contact } & Low & 47 & 39.17 \\
\hline & Medium & 55 & 45.83 \\
\hline & High & 18 & 15.00 \\
\hline \multirow[t]{3}{*}{ Mass media exposure } & Low & 42 & 35.00 \\
\hline & Medium & 60 & 50.00 \\
\hline & High & 18 & 15.00 \\
\hline \multirow[t]{3}{*}{ Innovativeness } & Low & 24 & 20.00 \\
\hline & Medium & 71 & 59.17 \\
\hline & High & 25 & 20.83 \\
\hline \multirow{3}{*}{$\begin{array}{l}\text { Sources of information } \\
\text { utilisation. }\end{array}$} & Low & 33 & 27.50 \\
\hline & Medium & 63 & 52.50 \\
\hline & High & 24 & 20.00 \\
\hline \multirow{4}{*}{$\begin{array}{l}\text { Training in rice drum seeder } \\
\text { technology }\end{array}$} & Nil (no training ) & 16 & 13.33 \\
\hline & Low $(<2)$ & 35 & 29.17 \\
\hline & Medium (3-4) & 48 & 40.00 \\
\hline & $\operatorname{High}(>4)$ & 21 & 17.50 \\
\hline \multirow[t]{3}{*}{ Risk orientation } & Low & 32 & 26.67 \\
\hline & Medium & 52 & 43.33 \\
\hline & High & 36 & 30.00 \\
\hline
\end{tabular}

The study concluded that the majority profile characteristics of rice drum seeder farmers were middle aged, illiterate, medium farm size, had medium farming experience, extension contact, mass media exposure, innovativeness, source of information utilisation, training in rice drum seeder technology and risk orientation. Therefore the institutions engaged in agriculture should initiate new programmes to encourage drum 
seed technology among farming community for better income and yields and to meet the rice demand of country.

\section{References}

Anup, P.R.U., Padhyay, S.J., Taufiq, A.H and Singh, A.K. 2010. Evaluations of farm school on All India Radio on organic farming. Journal of Communication Studies.18 (5):131-132.

Arathy, B. 2011. Constraint analysis of rice farmers of Trissur district of Kerala. M.Sc. (Ag.) Thesis. Acharya N G Ranga Agricultural University, Hyderabad, India.

Gangadhar, J. 2009. Marketing behaviour of cotton farmers in Warangal district of Andhra Pradesh. M.Sc. (Ag.) Thesis. Acharya N G Ranga Agricultural University, Hyderabad. India.

Kiran, S and Shenoy, S.S. 2010. Constraints in adopt ion of system of rice intensification in Warangal district of Andhra Pradesh. Journal of Research ANGRAU. 38(1\& 2): 77-85.

Manjunath, T. 2010. A study on knowledge and adoption of plant protection measures by Paddy growers of Raichur district. M. Sc. (Ag.) Thesis. University of Agricultural Sciences, Dharwad, India.

Nagadev, B and Venkataramaiah, P. 2007. Characteristics of Integrated Pest Management (IPM) trained dry paddy farmers. The Andhra Agricultural Journal. 54(3\&4):240-242.

Nirmala, K. 2012. A study on diffusion status and adoption of System of Rice Intensification (SRI) in Mahaboobnagar district of Andhra Pradesh. M.Sc. (Ag.) Thesis. Acharya N G Ranga Agricultural University, Hyderabad, India.

Praveen babu, R., Sivanarayana, G and Gopikrishna, T. 2014. Knowledge level of paddy farmers in East Godavari District of Andra Pradesh. International journal of tropical agriculture. 33 (2): 1727-1730.

Prasad, R.C.C. 2002. A study on the impact of On-Farm Extension Demonstrations (OFEDs) in Rice in Nellore district of Andhra Pradesh. M.Sc. (Ag.) Thesis. Acharya N G Ranga Agricultural University, Hyderabad, India.

Shamna. N. 2015. A study on farmer's perception on prospects and problems of Pokkali rice farming in the state of kerala. M.Sc (Ag.) Thesis. Professor Jayashankar Telangana State Agricultural University, Hyderabad, India.

Sowjanya, R.G. 2005. A study on the sustainability of sugarcane cultivation in Visakhapatnam district of Andra Pradesh. Ph. D Thesis. Acharya N G Ranga Agricultural University, Hyderabad, India.

Viresh, K and Kiran, M. 2007. Knowledge level of the Paddy farmers on integrated management practices in Sindhudurga district of Maharashtra. M.Sc. (Ag.) Thesis. University of Agricultural Sciences, Dharwad, India.

\section{How to cite this article:}

Naresh Kumar, B., M. Sreenivasulu, M. Preethi and Vidya Sagar, G.E.CH. 2019. Profile Characteristic of Rice Drum Seeder Technology Farmers in Khammam District of Telangana State, India. Int.J.Curr.Microbiol.App.Sci. 8(03): 1180-1184.

doi: https://doi.org/10.20546/ijcmas.2019.803.139 